\title{
Actio Pro Socio in a Public Limited Company in Slovenian and German Legal System
}

\author{
Sara Ahlin Doljak, Ph.D. \\ Assist. Prof. at the European \\ Faculty of Law (EVRO-PF) \\ Slovenia and lawyer in Law Firm
}

\begin{abstract}
The article entitled »Actio pro socio in Slovenian and German legal system « is a heterogeneous article because only a detailed definition of the action in both legal systems, breakdown of the characteristics of both systems, and the comparison of both systems can expose all of the relevant particularities of the assertion of claims of the company by shareholders. In both systems, the actio pro socio developed as a result of the need to provide the minority of shareholders with a chance to correct the inactivity or incorrectness of the company's bodies or shareholders that control the company. The action is used to assert the claims belonging to the company and not to an individual shareholder. An individual shareholder must, therefore, first try to lodge the action through competent bodies of the company. Lodging of the action by a minority of shareholders usually occurs when a majority of shareholders obstructs the action to be lodged by the company. The starting point for this text was the definition of the phenomenon actio pro socio in company law as an action which allows the minority of shareholders to assert company's claims deriving from shareholding relationship. The Slovenian Companies Act is predominantly based on the German-Austrian legislative regulation. This resulted in a similar actio pro socio which is why this article also addresses the German regulation of the actio pro socio in companies law. Even though the purpose of the action lodged by a minority of shareholders is to protect the interests of the company and to support effective management of the company, unjustified actions may still occur. The costs of the proceeding are certainly an important factor when deciding to lodge the action. A special chapter is therefore devoted to the costs of the proceeding when lodging the actio pro socio.
\end{abstract}

Keywords: actio pro socio, public limited company, costs of the proceeding, Companies Act, German AktG

\section{Introduction}

The actio pro socio owes its applicability and development in corporate law to case-law and legal theory that has been developing on the basis of the partnerships model. ${ }^{1}$ In limited companies, this action was first acknowledged in limited liabilities companies ${ }^{2}$, whilst in joint stock company law, its application as a form of the minority right of shareholders, only started in recent years. The reasons for its late recognition in public limited companies can be found in strict separation of the company and shareholders and in legally defined mandatory competencies of company's bodies.

Lodging of the claims by minority shareholders raises the question of who shall bear the (judicial) costs of such a proceeding. Costs of such proceeding often play the decisive role when shareholders decide whether to lodge an action in favour of the company or not. High judicial costs of the proceeding can discourage shareholders from lodging the (otherwise justified) claim which can result in negligent actions of the shareholders and management bodies. On the other hand, it is unreasonable to always impose the payment of the costs on the public limited company because this may result in excessive lodging of unjustified claims. The actio pro socio is therefore in particular intended for the benefit of the public limited company and for its proper management, however, unjustified lodging of claims may still occur.

\section{Arrangement of the Actio Pro Socio in Slovenian Legislation in Public Limited Companies}

The main characteristic of a public limited company is that the personified capital ${ }^{3}$ represents the bearer of the rights and obligations in the company. Assets plc. represents independent assets of the public limited company as a legal entity. Shareholders are not the owners of the company, but exercise their property and membership rights from the paid-up shares. A public limited company allows accumulation or pooling of small capitals in order to achieve positive effects of the concentration of large capital, and simultaneously excludes excessive risk taken by investors. It is essential that company's assets are separated from private or personal assets of the investors.

\footnotetext{
${ }^{1}$ Wiedemann H., ibidem, 1980, page 458.

${ }^{2}$ Wiedemann H., ibidem, 1980, page 463.

${ }^{3}$ Ivanjko Š., Kocbek M., Korporacijsko pravo - pravni položaj gospodarskih subjektov, GV Založba, Ljubljana, 2003 , page 426. 
By emphasising the legal entity, the legal existence of the company is completely separated from shareholders, and in legal terms the company represents an independent bearer of the rights and obligations. The legal owner of the company's assets is the company itself. The public limited company is the bearer of the economic structure and legal personality. Participation of shareholders in the company is only equity participation, and only such participation determines the extent of rights and obligations.

It is in the interest of the country ${ }^{4}$ to regulate public limited companies in detail, which is why the majority of provisions of the Companies Act (ZGD -1) are mandatory in nature. In joint stock company law the actio pro socio could not be established due to the strict separation of the company from the shareholders and the defined mandatory competencies of company's bodies. ${ }^{5}$ The amendment of the Companies Act (ZGD-1) established a similar minority right of shareholders as defined by Article 148 of the German $\mathrm{AktG}^{6}$.

As a rule, shareholders do not participate in the management of the public limited company because such partticipation is prevented by the dispersion of capital, i.e. number of shareholders participating in the public limited company, and the dynamics of company's operation. Management of company's operations is entrusted to the management ${ }^{7}$ or the Management board. The management is responsible for the operation of the company and especially represents the bearer of company's interests and must, on account of its nature and function, represent company's interests before the public limited company. The Companies Act (ZGD-1) therefore grants extensive powers to the management when adopting decisions related to company's operation. Management's freedom of action can only be seen within the framework of corporate enterprise (economic destiny of company's assets) and not within the framework of the company, except in the case when it acts as the implementer of decisions adopted by the bodies of the company. In representing the interests of the company, the management is by nature forced to make compromises between the interests of the public limited company and the company. ${ }^{8}$ The management decides on the economic destiny of public limited company's assets, whilst the shareholders as investors bear the entrepreneurial risk. ${ }^{9}$ The latter often results in the well-known problem of the relationship theory between the representee - representative. The legal formulation ${ }^{10}$ shows that the management directs the operations of the public limited company for the benefit of the public limited company, independently and on its own responsibility. We are talking about a relatively independent position of the management ${ }^{11}$ which is specific for public limited companies because the public limited company needs to be protected in some manner against harmful practices and decisions adopted by its shareholders. By interfering with daily business operation, shareholders could pursue their own interests and not the interests of the public limited company and thereby damage the interests of minority shareholders. ${ }^{12}$ On the other hand, it is possible to detect that the management is allowed to act in many different ways where it can pursue its own interests and not the interests of the public limited company, whilst the shareholders are often unable to effectively control such actions because of the lack of expertise and poor flow of information.

${ }^{4}$ Each legislative amendment in the public limited company must especially consider the procedural aspects of the enforcement of rights. In addition, incentives should be developed for faster and cheaper resolution of disputes and better organization of minority shareholders which must not remain only a personal initiative but an interest of the country to transfer the principles of political democracy and equal opportunities to the economic sphere.

${ }^{5}$ Schmidt K., Gesellschaftsrecht, Carl Heymanns Verlag KG, Köln, Berlin, Bonn, München, 1986, page 477 in Senčur D., Ibidem, 1996 , No. 5, page 684 and the following pages.

${ }^{6}$ Detailed analysis of Article 148 of the AktG is set out below, see https://www.gesetze-im-internet.de/aktg/.

${ }^{7}$ See Article 10 of the Companies Act (ZGD-1) Companies Act (Official Gazette of the Republic of Slovenia, No. 65/09 - official consolidated text, 33/11, 91/11, 32/12, 57/12, 44/13 - judicial decision of the Constitutional Court of the Republic of Slovenia, 82/13, $55 / 15$ and 15/17).

${ }^{8}$ Ivanjko Š., Nasprotje interesov v gospodarski družbi, Podjetje in delo, Ljubljana, 1999, No. 5, page 601.

${ }^{9}$ Bratina B., Vidiki odgovornosti uprave delniške družbe in razmerja pri odpoklicu, Podjetje in delo, Ljubljana, 1995, No. 5, page 640.

${ }^{10}$ See paragraph 1 of Article 265 of the Companies Act (ZGD-1).

${ }^{11}$ Legal formulation of the management of public limited companies indeed points at its independent position because of its competence to adopt all decisions regarding the management of operations, except for decisions which are under the competence of the Assembly and the Management board. The management cannot transfer the responsibility for decisions under its competence to other subjects by transfer of jurisdiction. The management may authorize its individual members or other persons to perform a certain business transaction and decide on certain questions, however, such persons may only perform such actions in the function of exercising the competencies of the management which is objectively responsible for actions of such persons as if such actions were performed by the management itself. It is impossible to deprive the management of its competencies. Management of business operations cannot be transferred to the Management board (paragraph 5 of Article 281 of the Companies Act (ZGD-1)). The Statute or the Management board may decide that certain business operations may only be performed by its consent. If the Management board refuses to grant its consent, the management may demand that the consent shall be decided upon by the vote of the majority of at least $3 / 4$ of the voters of the Assembly.

${ }^{12}$ Ivanjko Š., Kocbek M., Pravo družb, Statusno gospodarsko pravo, second amended edition, Ljubljana, ČZ Official Gazette of the Republic of Slovenia, 2001, page 300. 
It may easily occur that the management acts illegally or contrary to the statute of the public limited company. Actions of the management may sometimes be legal and still cause damage to the public limited company. ${ }^{13}$ To sum up, independence of the management certainly increases the risk for abuse which attributes greater importance to the interests of third persons than the interests of shareholders. ${ }^{14}$ The Companies Act (ZGD-1) legitimized the possibility of one-tier management of public limited companies. On the basis of paragraph 2 of Article 253 of the Companies Act (ZGD-1), the tasks of the Supervisory board are entrusted to the Management board. The problem arises when a claim is asserted on the basis of Article 283 of the Companies Act (ZGD-1). Such claim would probably fail. There is a clear need to amend this segment of the Act, i.e. question with the allocation of competencies regarding lodging of the mentioned claims for damages. The one-tier system of management requires an amendment of Worker Participation in Management Act (ZSDU) ${ }^{15}$. Participation of workers in the one-tier system of management is governed by Article 703 of the Companies Act (ZGD-1) which defines worker participation in bodies of such companies in accordance with the provisions of this Article until the enactment of the Worker Participation in Management Act which will regulate worker participation in management in companies with one-tier system of management. If this does not contravene the relevant Act, workers appoint their representative as one of the three additional members of the Management board and a representative of the Commission of the Management board in accordance with WPMA (ZSDU) regarding participation of workers in the Supervisory board of public limited companies. If a representative of workers is appointed to the Management board and if the public limited company employs more than 500 workers, the proposal of the Works council shall represent the basis for the Management board to appoint such representative as the executive director that shall perform the tasks of representation or representation of workers' interests related to human resource and social questions in accordance with WPMA (ZSDU). Workers are losing their active role in directing the operation of public limited companies and in control of rge managements of public limited companies because of the amendment of the WPMA (ZSDU) which abolished the deciding position of workers in Supervisory boards in large public limited companies and with constant decrease of the number of employees in public limited companies. ${ }^{16}$ Article 309 of the Companies Act (ZGD-1) allows the members of the management and the Management board to exercise their voting rights. If the members of the management manage to gain the authorizations ${ }^{17}$ to exercise their voting right, they have greater power at the Assembly. ${ }^{18}$ The actio pro socio would certainly present a solution for the cases mentioned above.

The basic type of the Slovenian public limited company is a large company with a small number of influential shareholders who, through joint actions, easily exclude small shareholders from the control of the public limited company. Company's claims for damages remain unrecovered as long as there is protection of the interests in the vertical structure of the majority shareholder, Supervisory board and the management. In order to prevent extortion actions, a preliminary proceeding regarding the admissibility of the actio pro socio should be implemented where the plausibility of the claim would be checked. In terms of the other legal mechanisms within the organization of the public limited company, the shareholder's action is subsidiary, which is why the shareholder should, as a procedural requirement, prove that, with the claim delivered to the president of the Supervisory board which is, according to Article 283 of the Companies Act (ZGD-1) responsible for the assertion of the claim against the members of the management, he tried to assert the claim within the framework of the mandatory distribution of competencies within the public limited company.

${ }^{13}$ In case the management fails to honour its corporate duty of loyalty or misses a business opportunity. Such actions may result in loss of profit which reflects in business success.

${ }^{14}$ See paragraph 2 of Article 32 of the Companies Act (ZGD-1) in relation to paragraph 1 of Article 265 of the Companies Act (ZGD-1).

${ }^{15}$ Official Gazette of the republic of Slovenia, No. 42/1993, last amendment, Official Gazette of the Republic of Slovenia, No. 56/2001.

${ }^{16}$ Participation of employees in the management of public limited companies in Slovenia is governed by the Worker Participation in Management Act (ZSDU), whilst the participation in profit of public limited companies is supposed to be governed by a special act. Labour and corporate regulations already allow participation of workers in profit of public limited companies. The Companies Act (ZGD-1) also enables employees to participate in profit of public limited companies, especially when it refers to the use of the net and the accumulated profit, distribution amongst the shareholders and other purposes (payments to employees, members of the Management board and the Supervisory board) (paragraph 6 of Article 230 of the Companies Act (ZGD-1)). Public limited companies may provide its employees with a chance to participate in profit which does not indicate payment for work - salary (this is governed by labour regulations) but direct participation in profit. Such decision must be adopted at the Assembly of the public limited company and requires legal foundation in law or the statute. Because there is currently no legal foundation in Slovenia for such decision by the Assembly, such decision requires statutory definition. The Companies Act (ZGD-1) does not define labour aspects of the participation of workers in profit of public limited companies, which is why such aspects must be found in labour regulations and at the level of collective contracts. Besides the salary, workers may be granted reward for their work, which is one of the criteria for determination of the salary.

${ }^{17}$ See paragraph 7 of Article 309 of the Companies Act (ZGD-1).

${ }^{18}$ Bratina B., Korporacijskopravni status organov kapitalskih družb po slovenski zakonodaji, doctoral thesis, Pravna fakulteta v Mariboru, 1997, page 131. 
If, however, this does not initiate the compensation procedure, the shareholder should have the opportunity, to lodge an action on his own behalf against the member of the management in favour of the public limited company. ${ }^{19}$ Due to the lack of substantive entitlement, the shareholder is bound by the Assembly's decision. The correctness of the decision adopted by the Assembly can be checked with a judicial (litigation) proceeding where the credibility of the shareholder's claim is checked. ${ }^{20}$ In practice, the assertion of the public limited company's claim through a special representative $^{21}$ is not useful because the interests of the majority of the Assembly usually overlap with the interests of the Supervisory board which is why it cannot resolve the conflict of interests between the President of the Supervisory board and the responsible member of the management or the Management board against which the President of the Supervisory board should bring action against. ${ }^{22}$

\section{Comparison of Actio Pro Socio in German and Slovenian Law}

In German as well as in Slovenian law, an individual shareholder is not entitled to directly review business books, documents, contracts and other documents of the company. In case of suspicion of irregularity, minority shareholders may, on the basis of AktG, require designation of authorized experts to check whether the company's affairs were conducted correctly. ${ }^{23}$ The Companies Act (ZGD-1) leaves the decision regarding the sanctioning of offenders in operation of public limited companyies exclusively to shareholders and does not give power to initiate appropriate procedures neither to auditors nor other subjects outside the public limited company. ${ }^{24}$ This minority right related to the minority right to assert the company's claims is of great importance to ensure correct management of the public limited company. ${ }^{25}$ German law defines the minority right in public limited companies which allows the minority to avoid the arbitrariness of the management or the Management board and the majority, and represents some sort of a subsidiary body of the company. Minority rights are granted to the minority for situations where the controllers of the public limited company fail to meet their obligations. In practice, the legislative options of minorities are rarely realized and the purpose of such provisions is often of a preventive nature only. The companies Act (ZGD-1) also defines the right to demand the assertion of company's claims as a minority right, which means that an individual shareholder is not entitled to lodge an action on behalf of the public limited company. Minority rights are intended to ensure and maintain the correct management of the company. ${ }^{26}$ On behalf of the company, claims are usually asserted by the management of the public limited company. A delicate situation arises when a member of the management, who failed to meet his obligations, or a third person that abused its influence, is also a controlling shareholder ${ }^{27}$ In similar cases, the protection of the interests of the public limited company and assertion of the claims of the company may be performed by minority shareholders. The minority may avoid the arbitrariness of the management or the Management board and also the majority, and may represent some sort of a subsidiary body of the company.

In judicial practice in Slovenia, the actions against the members of the management and the Management board constitute a significant innovation. There will be no optimal management, efficient control of the members of the Management board and the need for management liability insurance until we will be able to see the first serious charges of the offenders of their obligations amongst the members of the management composition. The members of the management and the Supervisory board must exercise their competencies and obligations in a conscientious and fair manner and with due care and diligence, although this is not always the case. The underactive role of Supervisory boards is one of the major weaknesses of the Slovenian corporate management system. Supervisory boards are often inefficient in exercising their powers and consequently also their supervisory responsibility over the operation of the management. ${ }^{28}$ Competencies of the Supervisory board are defined in Article 281 of the Companies Act (ZGD-1). An efficient judicial practice would be able to define the behavioural pattern of the members of the management composition within the limits of the Companies Act (ZGD-1) where it would take into account the limitation of the legal doctrine. ${ }^{29}$ Exercise of competencies and obligations of members of the management and the Management board in accordance with the prescribed provisions of the law largely depends on the judicial practice and not legal doctrine.

\footnotetext{
${ }^{19}$ Ulmer P., ibidem, 1999, page 295.

${ }^{20}$ Becker M., Verwaltungskontrolle durch Gesellschafterrechte: eine vergleichende Studie nach. deutschem Verbandsrecht und dem amerikanischen Recht der corporation, Mohr Siebeck Verlag, Tübingen, 1997, page 656.

${ }^{21}$ See paragraph 3 of Article 327 of the Companies Act (ZGD-1).

${ }^{22}$ Wenger E., Stellungnahme zur Aktienrechtsreform 1997, in Die Aktiengesellschaft, 1997, page 57.

${ }^{23}$ See paragraph 2 of Article 142 of the AktG.

${ }^{24}$ Senčur D., Ibidem, 1998, No. 6, page 8, 10.

${ }^{25}$ Kocbek Marijan, Izredna revizija letnega poročila, Podjetje in delo, 2001, No. 2, page 303.

${ }^{26}$ Senčur D., ibidem, 1998, No. 6, page 810.

${ }^{27}$ Senčur D., ibidem note above.

${ }^{28}$ Peklar F. L., Nadzorniki morajo dvomiti, Delo, Ljubljana, No. 22, 2003, page 15.

${ }^{29}$ E.g. Article 272 of the Companies Act (ZGD-1) (reports to the Supervisory Board).
} 


\section{Costs of the Procedure In Case of the Action of Minority Shareholders - Comparison of the German and Slovenian Legislation}

In German legal system, there is a general rule called the English rule ${ }^{30}:$ "The unsuccessful party shall bear all costs associated with the judicial proceeding." These costs include the costs of the authorized person of the opposite party (Anwaltskosten) and judicial costs (Gerichtskosten) that can be defined as payments of various fees and charges. ${ }^{31}$ In accordance with this rule, the German legislative body also regulated the question regarding the coverage of the costs of the procedure with the new minority right - action which the minority shareholders may lodge on their own behalf.

Company's damage claim which is the result of the infringement in the establishment of the public limited company and its management ${ }^{32}$ may be lodged in the alternative - if the Assembly of the public limited company does not adopt an appropriate decision by a simple majority - on behalf of minority shareholders whose participation in the share capital equals $1 \%$ or whose total minimum emission amount of shares amounts to EUR $100,000 .{ }^{33}$ In order to prevent minority shareholders to abuse their entitlement, the German law stipulates that they have to negotiate a preliminary approval of the court for such action. A special preliminary approval procedure was established (Klagezulassungsverfahren; Art. $148 \mathrm{AktG}$ ). If in this procedure, which is a form of a non-litigious procedure, the minority negotiates a decision of the court which allows it to lodge an action, the minority shareholders are allowed to lodge an actio pro socio. The German legislator wants to use the approval procedure to prevent the minority from abusing its right. ${ }^{34}$

The preliminary approval procedure involves certain costs which shall be borne by the proposers (minority of shareholders) if the court refuses the request of the minority to allow the actio pro socio. ${ }^{35}$ This is not always the case. If the court refuses the request of the minority to allow the actio pro socio because the public limited company, prior to the initiation of the preliminary approval procedure, failed to inform the shareholders about the reasons and the facts which are not in favour of lodging the actio pro socio, the public limited company must reimburse the minority shareholders for the costs of the (unjustified) approval procedure. ${ }^{36}$ Such solution is reasonable because the minority shareholders, having knowledge of the relevant facts, probably would not initiate the approval procedure. From the fundamental shareholder's right to be informed, it is evident that the public limited company is obliged to inform the shareholders (on demand) in timely manner about the issues related to establishment and operation of the public limited company.

When the action by the minority shareholders is allowed, the final judgement, issued on the basis of the actio pro socio, shall define the bearer of the costs of the approval procedure. ${ }^{37}$ If the request of the minority shareholders is granted, the entire costs of the procedure shall be borne by the opposite party (in accordance with the success principle) who shall have to reimburse the plaintiff shareholders for the costs of their procedure.

The public limited company is constantly entitled to lodge its own damage claims. ${ }^{38}$ If the public limited company after the minority already brought a judicial proceeding (e.g. lodged a request for approval of the actio pro socio) lodges or accepts an action, it shall also bear the costs incurred by the minority by the date when the public limited company lodged the action (costs of the approval procedure as well as costs of the actio pro socio) or by the date when the public limited company accepts the action from the minority shareholders. ${ }^{39}$ In the continuation of such procedure e.g. after the public limited company accepts the action - the question regarding the coverage of the costs incurred by minority shareholders is no longer legally relevant because the public limited company acts as the client in the procedure and also bears the costs of the legal proceeding.

If the claim is partially or completely refused in the actio pro socio, the public limited company must reimburse the plaintiffs for the costs, unless the plaintiffs negotiated the approval of the court to lodge the actio pro socio on the basis of incorrect/false proposal provided intentionally or with gross negligence. ${ }^{40}$

\footnotetext{
${ }^{30}$ English Rule.

${ }^{31}$ Article 91 of the Zivilprozeßordnung (ZPO), see https://www.gesetze-im-internet.de/zpo/

${ }^{32}$ See paragraph 1 of Article 147 of the AktG.

${ }^{33}$ See paragraph 1 of Article 148 of the AktG.

${ }^{34}$ Kropff B., Semler J., Münchener Kommentar zum Aktiengesetz, Verlag C. H. Beck/Verlag Franz Vahlen, München, 2004, page 788.

${ }^{35}$ Paragraph 6, sentence 1 of Article 148 of the AktG.

${ }^{36}$ Paragraph 6, sentence 2 of Article 148 of the AktG.

${ }^{37}$ Paragraph 6, sentence 3 of Article 148 of the AktG.

${ }^{38}$ For details see paragraph 3 of Article 148 of the AktG.

${ }^{39}$ See paragraph 4, sentence 6 of Article 148 of the AktG. After lodging such action, the public limited company is also strictly restricted by law in terms of the possibilities of its withdrawal.

${ }^{40}$ See paragraph 6, sentence 5 of Article 148 of the AktG.
} 
If the public limited company already reimbursed minority shareholders for the costs of the preliminary approval procedure, where the minority negotiated a decision by the court to lodge the actio pro socio with an incorrect proposal, the public limited company is entitled to recover its payment. In case of obviously unjustified claims, the public limited company is entitled to recover the costs of the procedure from the shareholders that lodged the claim for the allowance of the actio pro socio.

The fundamental criterion for determination of the bearer of the costs of the actio pro socio is the result of the preliminary approval procedure. If the minority of shareholders in the preliminary approval procedure negotiate a decision by which the court allows the actio pro socio even in the case of failure in the continuation of the legal action (actio pro socio), the minority of shareholders generally do not bear the costs of the procedure. The minority of shareholders shall cover the costs of the actio pro socio procedure, where the claim in favour of the public limited company shall be refused, only if the minority of shareholders can be accused of gross negligence or intention at the time of lodging the proposal for initiation of the preliminary approval procedure. ${ }^{41}$ If in the non-contentious approval procedure, the minority of shareholders proves the existence of justified reasons for the actio pro socio and the court, on this basis, issues a decision to allow the minority shareholders to lodge an action on behalf of the company, the minority shall not bear the costs of the procedure despite of the refused claim in the actio pro socio. Such costs shall be borne by the public limited company. During the time until the final decision is issued in the actio pro socio, regular payments are covered by the party to the procedure - i.e. minority of shareholders when the actio pro socio is lodged on its behalf where the minority of shareholders has the recourse right against the public limited company.

\section{Conclusion}

Two-tier system of management of public limited companies at least theoretically allows the structure where the conflict of interests in deciding about the action may be avoided or at least more efficiently addressed than in the onetier system of management. In the German two-tier system, the Supervisory board makes decisions regarding the claims of the public limited company against the members of the management ${ }^{42}$, whilst the Management board (management) is entitled to lodge an action against the members of the Supervisory board ${ }^{43}$ (AktG approach). It is essential that decisions regarding the action are in the hands of a group not burdened by conflict of interests. The basic condition here is the rule of incompatibility of functions which prevents simultaneous membership of an individual in management and the Supervisory board. ${ }^{44}$

In theory, the AktG approach for the prevention of the conflict of interests in deciding about an action seems attractive. In practice however, there are many reasons indicating that such approach can be ineffective.

It is possible to notice that the two-tier system of management which provides active legitimation for lodging of the claim only to the Supervisory board (claims against the members of the management) and the management (claims against the members of the Supervisory board) and not to shareholders, does not provide sufficient guarantee in cases when the action I directed against the management as well as the Supervisory board. ${ }^{45}$ Active legitimation of (minority) shareholders to lodge an action, which is defined in Article 148 of the AktG, therefore represents a fail-safe system which allows the claim to be lodged in cases when the members of the primary responsible body do not take any actions or in cases when they are protected by the solidary or personally connected majority of shareholders. Article 148 of the AktG can be determined as the method which regulates the conflict of interests in administrative bodies as well as the problems with the control of offenders, i.e. the problem which can be caused by the influence of the majority shareholder.

Minority rights, defined in paragraphs 1 and 2 of Article 148, can also be called secondary or support mechanisms. They are usually considered as substitute authorization which can only be used if the primary responsible body of the public limited company does not take any action or does not want to claim compensation for the damage caused to the public limited company. Minority rights are therefore based on realization that in certain circumstances the responsible bodies do not guarantee the enforcement of claims of the public limited company. ${ }^{46}$ Besides the original competencies of the Supervisory board, management and the shareholders Assembly, lodging of the claim also requires a new minority right. ${ }^{47}$

\footnotetext{
${ }^{41}$ See paragraph 6, sentence 5 of Article 148 of the AktG (...sofern nicht die Kläger die Zulassung durch vorsätzlich oder grob fahrlässig unrichtigen Vortrag erwirkt haben...).

${ }^{42}$ See Article 112 of the AktG.

${ }^{43}$ See paragraph 1 of Article 78 of the AktG.

${ }^{44}$ See Article 105 of the AktG.

${ }^{45}$ Baums T., ibidem, 2000, page 242.

${ }^{46}$ Peltzer M., ibidem, 2002, page 14.

${ }^{47}$ Schmidt K., Gesellschaftsrecht, 3rd ed., Heymanns, Köln, 1997, page 643.
} 


\section{Sources and Bibliography}

Baums T., Empfiehlt sich eine Neuregelung des aktienrechtlichen Anfechtungs- und Organhaftungsrechts, insbesondere der Klagemöglichkeiten von Aktionären?, C.H. Beck, München, 2000.

Becker M., Verwaltungskontrolle durch Gesellschafterrechte: eine vergleichende Studie nach. deutschem Verbandsrecht und dem amerikanischen Recht der corporation, Mohr Siebeck Verlag, Tübingen, 1997.

Bratina B., Korporacijskopravni status organov kapitalskih družb po slovenski zakonodaji, doktorska disertacija, Pravna fakulteta v Mariboru, 1997.

Bratina B., Vidiki odgovornosti uprave delniške družbe in razmerja pri odpoklicu, Podjetje in delo, št. 5, Ljubljana, 1995.

Ivanjko Š., Kocbek M., Korporacijsko pravo - pravni položaj gospodarskih subjektov, GV Založba, Ljubljana, 2003.

Ivanjko Š., Kocbek M., Pravo družb, Statusno gospodarsko pravo, druga spremenjena in dopolnjena izdaja, Ljubljana, ČZ Ur. 1. RS, 2001.

Ivanjko Š., Nasprotje interesov v gospodarski družbi, Podjetje in delo, št. 5, Ljubljana, 1999.

Kocbek M., Izredna revizija letnega poročila, Podjetje in delo, št. 2, Ljubljana, 2001.

Kropff B., Semler J., Münchener Kommentar zum Aktiengesetz, Verlag C. H. Beck/Verlag Franz Vahlen, München, 2004.

Peklar F. L., Nadzorniki morajo dvomiti, Delo, Ljubljana, št. 22, 2003.

Peltzer M., Corporate Governance Codices als zusätzliche Pflichtenbestimmung für den Aufsichtsrat, 5 N.Z.G. 10, 2002.

Schmidt K., Gesellschaftsrecht, 3. Aufl., Köln: Heymanns, 1997.

Schmidt K., Gesellschaftsrecht, 3. Aufl., Köln: Heymanns, 1997.

Schmidt K., Gesellschaftsrecht, Carl Heymanns Verlag KG, Köln, Berlin, Bonn, München, 1986.

Senčur D., Actio pro socio in derivativna tožba, Podjetje in delo, št. 5, 1996.

Senčur D., Pravice manjšinskih delničarjev v zvezi s sklepi skupščine, Podjetje in delo, št. 6, 1998.

Senčur D., Varstvo manjšinskih delničarjev, Gospodarski vestnik, Ljubljana, 1998.

Ulmer P., "Die Aktionärsklage als Instrument zur Kontrolle des Vorstands - und Aufsichtsratshandelns", 163 Z.H.R. 290, 1999.

Wenger E., Stellungnahme zur Aktienrechtsreform 1997, v Die Aktiengesellschaft, 1997.

Wiedemann H., Gesellschaftsrecht, Band I, München 1980.

Zakon o gospodarskih družbah (Uradni list RS, št. 65/09 - uradno prečiščeno besedilo, 33/11, 91/11, 32/12, 57/12, $44 / 13$ - odl. US, 82/13, 55/15 in 15/17)

https://www.gesetze-im-internet.de/aktg/

https://www.gesetze-im-internet.de/zpo/ 